$\xi_{p}=$

\title{
Study the effects of calcinations and evolution of crystallographic parameters of two Tunisian natural phosphates
}

\author{
A. Chaabouni ${ }^{1}$, C. Chtara ${ }^{2}$, A. Nzihou ${ }^{3}$, H. El Feki ${ }^{1 *}$ \\ ${ }^{1}$ Laboratory of sciences of materials and environment, faculty of sciences of sfax, sfax, Tunisia \\ ${ }^{2}$ Tunisian chemical group, gabes, Tunisia \\ ${ }^{3}$ Engineering school of mines of albi-carmaux, Toulouse, France \\ *Corresponding author E-mail: hafed.elfeki@yahoo.fr
}

\begin{abstract}
Tunisian natural phosphate is a highly form of fluorapatite, carbonate fluorapatite, also known as "francolite". The presence of carbonate in mineral phosphates influences their reactivity overlooked acid attack, but their presence requires a supplementary adding of sulfuric acid in the plants of production of phosphoric acid; and causing the formation of foams in the reactors during the addition of sulfuric acid. The presence of carbonates in high contents reduces the price value of phosphate rock.

We propose in this work to study thermally the decomposition of two carbonated fluorapatite in a range of temperature between ambient and $1000^{\circ} \mathrm{C}$; and the variation of the value of crystallographic parameters of the two samples of phosphate. The X-ray diffraction technique is used for this mineralogical study.

By referring to the crystallographic parameters of the lattice of phosphate, we note that the increase in temperature decarbonated the francolite which is transformed largely to a fluoroapatite. In addition, it was reported that the first decarbonation is around $650^{\circ} \mathrm{C}$ translated the kinetics of decomposition of the carbonate ions of the type B associated with a vaccum, while the second decarbonation is around $1000^{\circ} \mathrm{C}$ and related to the thermal decomposition of the entity of $\mathrm{CO}_{3} \mathrm{~F}$, generated by the decomposition of carbonate ions of type $\mathrm{B}$ and $\mathrm{A}$. The presence of these ions would be the result of a reorganization of the crystal lattice.
\end{abstract}

Keywords: Carbonated fluoroapatite, effect of calcinations, mineralogical study, Tunisian natural phosphate, x-ray diffraction.

\section{Introduction}

Tunisian natural phosphate is an essential element used in the plants of production of phosphoric acid. It is a highly form of fluorapatite, carbonate fluorapatite, also known as "francolite" (CHAABOUNI et al. 2013, Jahnke 1984, McConnell 1973). The structure of apatite can be described in terms of an approximate hexagonal close packed set of spheres in which each sphere represents a tetrahedral $\mathrm{PO}_{4}{ }^{3-}$ ion. It is well established that carbonate substitution has a destabilizing effect on the apatite structures resulting in increased solubility (CHAABOUNI et al. 2013, Chien et al. 1976, Jahnke 1984). In addition, the presence of carbonates in the mineral phosphates greatly influences their reactivity towards acid attacks (Lehr et al. 1972). The presence of carbonates requires a supplementary add of sulfuric acid during the production of phosphoric acid; in addition to it causes foaming which inhibits the cooling of the reaction. Accordingly an increasing in temperature and viscosity of the phosphoric slurry; which leads to the formation of the hemihydrate phosphogypsum, it results a bad filtration which affects the quality of the phosphoric acid product and decreases the chemical yield (Becker 1989, SLACK 1968, Waggaman 1953).

Apatites have the general formula, $\mathrm{Ca}_{10}\left(\mathrm{PO}_{4}\right)_{6} \mathrm{X}_{2}$ where $\mathrm{X}$ is typically $\mathrm{F}$ (fluorapatite, FAp), $\mathrm{OH}$ (hydroxyapatite, OHAp), or $\mathrm{Cl}$ (chlorapatite, ClAp). The apatite lattice is very tolerant of substitutions, vacancies and solid solutions, for example, $\mathrm{X}$ can be replaced by $1 / 2 \mathrm{CO}_{3}$ or $1 / 2 \mathrm{O} ; \mathrm{Ca}$ by $\mathrm{Sr}, \mathrm{Ba}, \mathrm{Pb}$,
$\mathrm{Na}$ or vacancies; and $\mathrm{PO}_{4}$ by $\mathrm{HPO}_{4}, \mathrm{AsO}_{4}, \mathrm{VO}_{4}, \mathrm{SiO}_{4}$ or $\mathrm{CO}_{3}$ (Elliott 1994).

Beneficiation by calcinations is one of the well known processes. It is based on the dissociation of the calcium carbonate by thermal energy. Depending on the efficiency of the process, calcinations may lead to almost complete disposal of the carbonates present in the phosphate rock (Kumar 1980, Memminger et al. 1930, Ozer 2003).

There are two types of carbonate apatite:

The carbonate apatite of type $\mathrm{A}$ in which $\mathrm{CO}_{3}{ }^{2-}$ ions are fixed along the senaire helical axis where usually located the monovalent anions (Bonel 1972, Trombe et al. 1967).

The carbonate apatite of type $\mathrm{B}$ in which $\mathrm{CO}_{3}{ }^{2-}$ ions occupied the sites of phosphate ions (Bonel 1972, Legeros 1967, Legeros et al. 1964, Vignoles 1973) with creation for each substitution, a lacuna in a calcium site and the other in oxygen site and the third in the tunnels site.

It is noted that the crystallographic parameter "a" of carbonated hydroxyapatites containing sodium ions increases by adding carbonates content, while parameter "c" decreases (Bonel 1972, Memminger et al. 1930, Ozer 2003, Trombe et al. 1967).

In this work, we studied the temperature of calcinations and its effects on two sedimentary phosphates in a range of temperature between ambient and $1000^{\circ} \mathrm{C}$ and the effect of this increase on the crystallographic parameters "a" and "c" of these two samples. 


\section{Materials and methods}

The tests are performed on the laboratory scale in an adjustable furnace in temperature on the Tunisian phosphate. The study of the time of calcinations is carried out by introducing samples of phosphate in the furnace for a period of 60 minutes at a fixed temperature $\left(250^{\circ} \mathrm{C}, 650^{\circ} \mathrm{C}\right.$ and $\left.1000^{\circ} \mathrm{C}\right)$.

The powders were characterized by X-ray diffraction (DRX). The diffractograms are acquired with the radiation $\mathrm{K} \alpha$ of Copper ( $\mathrm{CuK} \alpha$ and the wavelength is $\lambda=1,541 \AA$ ) using a diffractometer SIEMENS D5000. Besides, the structural information was obtained starting from a powder diagram collected in the angular field 5-110 in $2 \mathrm{~h}$ with an angular step of $0.04^{\circ}(2 \mathrm{~h})$ and counting time of $5 \mathrm{~s}$. The refinement of the lattice parameters is achieved by WPF method (Whole Pattern Fitting or Le Bail method) using Fullprof Suite software version 1.10.

\section{Results and discussion}

The X-ray diffractograms are shown in fig. 1 and Fig. 2.

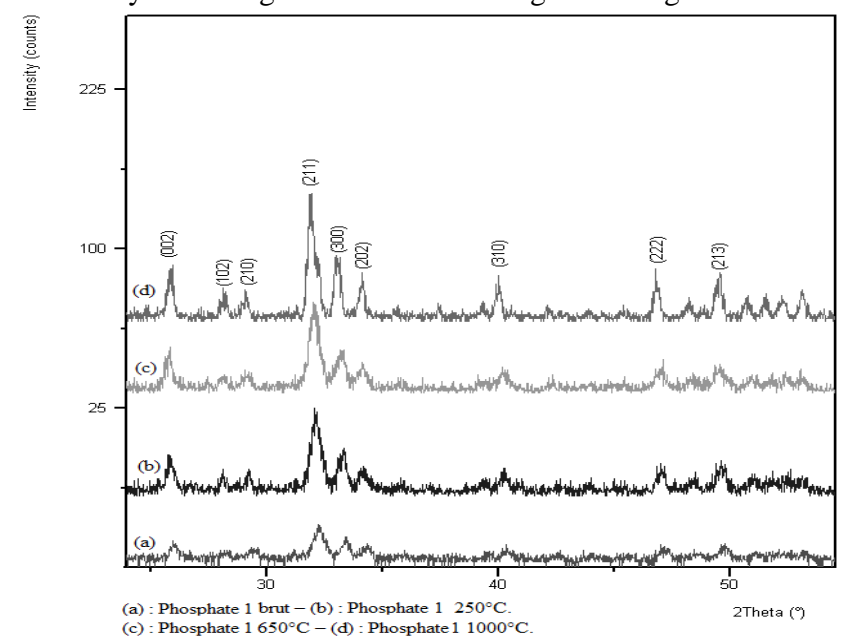

Fig. 1: X-Ray diffractograms of the sample of phosphate 1 at differen temperatures (ambient temperature, $250^{\circ} \mathrm{C}, 650^{\circ} \mathrm{C}$ and $1000^{\circ} \mathrm{C}$ ).

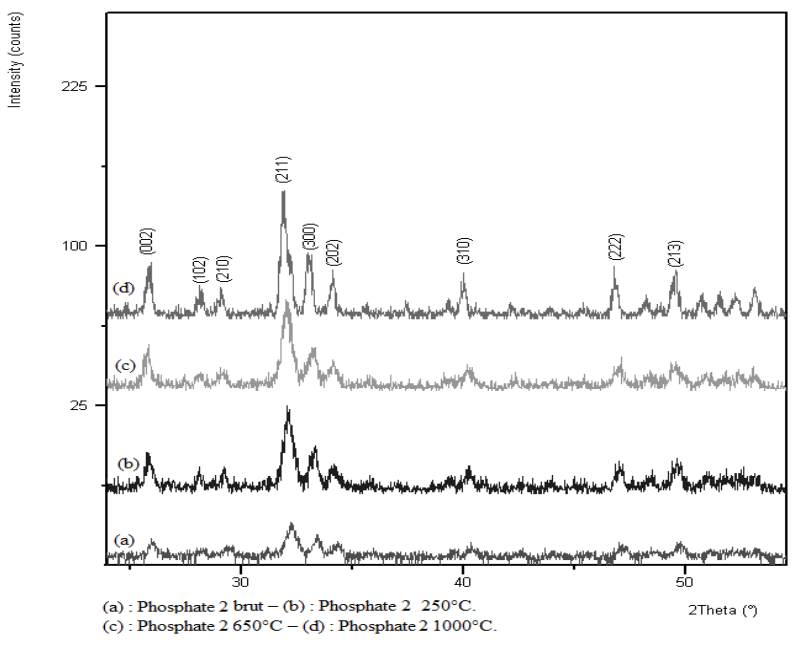

Fig. 2: X-Ray diffractograms of the sample of phosphate 2 at different temperatures (ambient temperature, $250^{\circ} \mathrm{C}, 650^{\circ} \mathrm{C}$ and $1000^{\circ} \mathrm{C}$ ).

The diffractograms of phosphates presents fine lines. The analysis of this diagram by isotopy with the charts of reference (Trombe 1973, Young 1973), show that the solids crystallize in the hexagonal system and have $\mathrm{P}_{3} / \mathrm{m}$ symmetry. The crystallographic parameters of phosphate rocks and those of references (Trombe 1973, Young 1973) are shown in table 1.
Table 1: Crystallographic parameters of phosphate rocks and those of references (Trombe 1973, Young 1973).

\begin{tabular}{llll}
\hline & Parameter a & Parameter b & Parameter c \\
\hline Phosphate 1 & 9.327 & 9.327 & 6.894 \\
Phosphate 2 & 9.337 & 9.337 & 6.909 \\
Hydroxy-Ap & 9.421 & 9.421 & 6.882 \\
Fluoro-Ap & 9.372 & 9.372 & 6.888 \\
Francolite & 9.360 & 9.360 & 6.890 \\
\hline
\end{tabular}

At room temperature, by comparison between the crystallographic parameters of the two samples of phosphates and those of references $(\mathrm{a}=9,327 \AA$ for the sample of phosphate 1 , and $\mathrm{a}=9,337 \AA$ for the sample of phosphate 2) and those hydroxyapatite $(\mathrm{a}=9.421 \AA)$, fluoroapatite $(\mathrm{a}=9.372 \AA)$ and the francolite $(\mathrm{a}=9.360 \AA)$. This proves that our fluorapatite is carbonated and it is a francolite (Trombe 1973, Young 1973).

The calculation of the crystallographic parameters of each sample at various temperatures and which are recapitulated in table 2 and table 3 , shows that the volume of the crystallographic mesh of the crude phosphate $2\left(\mathrm{~V}=521,733 \AA^{3}\right)$ is larger than that of crude phosphate $1\left(\mathrm{~V}=519,294 \AA^{3}\right)$; this is explained by the presence of much more $\mathrm{OH}^{-}$ions than of $\mathrm{F}^{-}$ions in the crude phosphate 2 than in the crude phosphate 1 , knowing that the ionic $\mathrm{F}^{-}$ray $(1,33 \AA)$ is smaller than the ionic ray of $\mathrm{OH}^{-}(1,43 \AA)$.

Table 2: Evolution of crystallographic parameters according to the temperature of the sample of phosphate 1

\begin{tabular}{lllll}
\hline & $\begin{array}{l}\text { Crude } \\
\text { phosphate }\end{array}$ & $\begin{array}{l}\text { Phosphate } \\
250^{\circ} \mathrm{C}\end{array}$ & $\begin{array}{l}\text { Phosphate } \\
650^{\circ} \mathrm{C}\end{array}$ & $\begin{array}{l}\text { Phosphate } \\
1000^{\circ} \mathrm{C}\end{array}$ \\
\hline $\begin{array}{l}\text { Temperature } \\
\left({ }^{\circ} \mathrm{C}\right)\end{array}$ & 25 & 250 & 650 & 1000 \\
$\mathrm{a}(\AA)$ & 9,327 & 9,3507 & 9,2912 & 9,3809 \\
$\mathrm{~b}(\AA)$ & 9,327 & 9,3507 & 9,2912 & 9,3809 \\
$\mathrm{c}(\AA)$ & 6,894 & 6,927 & 6,8571 & 6,8868 \\
$\alpha \square($ degrees $)$ & 90 & 90 & 90 & 90 \\
$\beta($ degrees $)$ & 90 & 90 & 90 & 90 \\
$\gamma($ degrees) & 120 & 120 & 120 & 120 \\
Symetry & Hexagonal & Hexagonal & Hexagonal & Hexagonal \\
Space group & $\mathrm{P} 6_{3} / \mathrm{m}$ & $\mathrm{P} 6_{3} / \mathrm{m}$ & $\mathrm{P} 6_{3} / \mathrm{m}$ & $\mathrm{P} 6_{3} / \mathrm{m}$ \\
Volume $\left(\AA^{3}\right)$ & 519,294 & 524,523 & 512,643 & 524,852 \\
Bragg R-Factor & 0,353 & 0,148 & 0,0969 & 0,364 \\
RF-Factor & 0,188 & 0,19 & 0,163 & 0,543 \\
\hline
\end{tabular}

Table 3: Evolution of crystallographic parameters according to the temperature of the sample of phosphate 2

\begin{tabular}{|c|c|c|c|c|}
\hline & $\begin{array}{l}\text { Crude } \\
\text { phosphate }\end{array}$ & $\begin{array}{l}\text { Phosphate } \\
250^{\circ} \mathrm{C}\end{array}$ & $\begin{array}{l}\text { Phosphate } \\
650^{\circ} \mathrm{C}\end{array}$ & $\begin{array}{l}\text { Phosphate } \\
1000^{\circ} \mathrm{C}\end{array}$ \\
\hline $\begin{array}{l}\text { Temperature } \\
\left({ }^{\circ} \mathrm{C}\right)\end{array}$ & 25 & 250 & 650 & 1000 \\
\hline $\mathrm{a}(\AA)$ & 9,33740 & 9,31680 & 9,33810 & 9,3858 \\
\hline b $(\AA)$ & 9,33740 & 9,31680 & 9,33810 & 9,3858 \\
\hline c $(\AA)$ & 6,9098 & 6,90110 & 6,90240 & 6,8954 \\
\hline$\alpha \square$ (degrees) & 90 & 90 & 90 & 90 \\
\hline$\beta$ (degrees) & 90 & 90 & 90 & 90 \\
\hline$\gamma$ (degrees) & 120 & 120 & 120 & 120 \\
\hline Symetry & Hexagonal & Hexagonal & Hexagonal & Hexagonal \\
\hline Space group & $\mathrm{P}_{3} / \mathrm{m}$ & $\mathrm{P}_{3} / \mathrm{m}$ & $\mathrm{P}_{3} / \mathrm{m}$ & $\mathrm{P}_{3} / \mathrm{m}$ \\
\hline Volume $\left(\AA^{3}\right)$ & 521,733 & 518,779 & 521,252 & 526,057 \\
\hline Bragg R-Factor & 0,762 & 0,811 & 0,779 & 0,284 \\
\hline RF-Factor & 0,643 & 0,39 & 0,656 & 0,573 \\
\hline
\end{tabular}

The representations of the crystallographic parameters according to the temperature are indicated on fig. 3 and fig. 4 .

Calcinations are primarily intended to decarbonise and dehydration an ore with a high grade in carbonates. During the heat treatment of mineral materials. Two solids capable of reacting giving to a monomolecular layer of the reaction product. The elements of the crystal lattice are in oscillatory motion whose intensity increases with increasing temperature. It is for this, the elements of the crystal lattice become able to overcome the force of attraction and change positions.

We note that there are fluctuations in parameters between ambient temperature and $250^{\circ} \mathrm{C}$. This is explained by a departure of 
the water of hydration and intercrystalline water (LABARTHE et al.1973, Vignoles 1984).

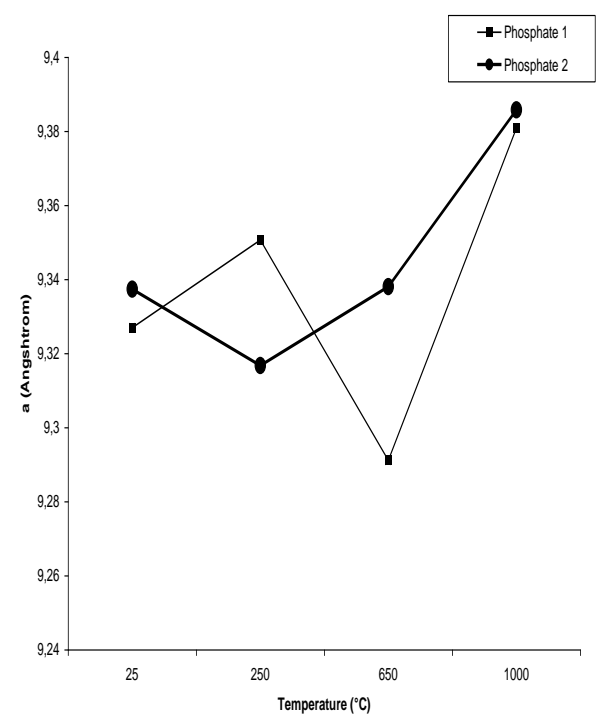

Fig. 3: Evolution of the crystallographic parameter "a" according to the temperature.

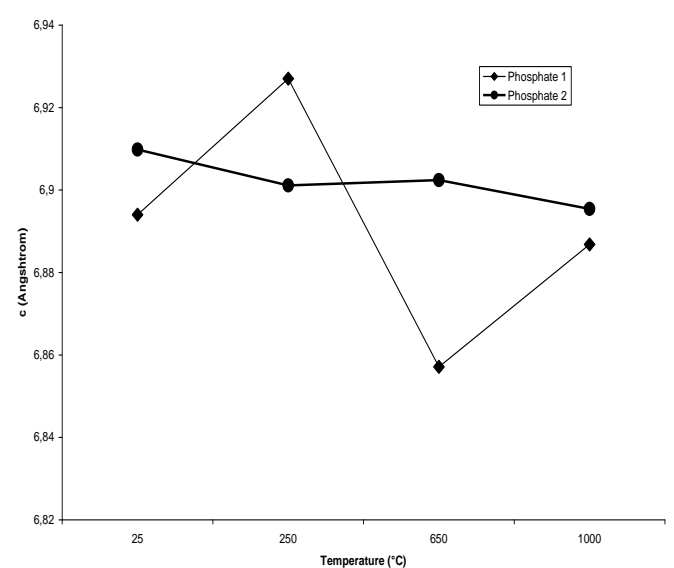

Fig. 4: Evolution of the crystallographic parameter "c" according to the temperature.

At the temperature $650^{\circ} \mathrm{C}$, there is a carbon dioxide emission that begins to volatilize from $600^{\circ} \mathrm{C}$ to $800^{\circ} \mathrm{C}$. This is a type $\mathrm{B}$ decarbonation which translates the kinetics of decomposition of the carbonate ions type $\mathrm{B}$ associated with a vaccum (EL FEKI et al. 1994, EL FEKI et al. 1991, EL FEKI et al. 1991, Lafon et al. 2002).

There is an emission of $\mathrm{CO}_{2}$ around $700^{\circ} \mathrm{C}$ that corresponds to the decomposition of $\mathrm{CaCO}_{3}$ presents in this powder of phosphate (Lafon et al. 2002).

At the temperature $1000^{\circ} \mathrm{C}$, there is a carbon dioxide emission that begins to volatilize from $800^{\circ} \mathrm{C}$ to $1050^{\circ} \mathrm{C}$ (EL FEKI et al. 1994 , EL FEKI et al. 1991, EL FEKI et al. 1991). This is a type A and $\mathrm{B}$ decarbonations. This is a result of thermal decomposition of the entity $\mathrm{CO}_{3} \mathrm{~F}$ generated by the decomposition of carbonate ions type A and B (EL FEKI et al. 1994, EL FEKI et al. 1991, EL FEKI et al. 1991). decarbonation of sites B which is accompanied by the appearance of $\mathrm{CaO}$ due to the restructuring of the crystal lattice (EL FEKI et al. 1994, EL FEKI et al. 1991, EL FEKI et al. 1991). At $1000^{\circ} \mathrm{C}$, by comparison between the crystallographic parameters of the two samples of phosphates $(\mathrm{a}=9,3809 \AA$ for the sample of phosphate 1 , and $\mathrm{a}=9,3858 \AA$ for the sample of phosphate 2) and those hydroxyapatite $(\mathrm{a}=9.421 \AA)$, fluoroapatite $(\mathrm{a}=9.372 \AA)$ and the francolite $(\mathrm{a}=9.360 \AA)$. This proves that after decarbonation, our francolite is similar to the fluoroapatite (Trombe 1973, Young 1973).

\section{Conclusion}

The heat treatment, in general and in the phosphate industry particularly is used in order to the valuation of raw ores, in their transformation into useful products, or even to transform raw materials into products directly.

The crystallographic parameters change depending on the temperature, which is the result of dehydration, and decarbonation type $\mathrm{A}$ or type $\mathrm{B}$.

Calcinations decrease the content of Carbonates in the samples of phosphate. Accordingly it allows decreasing the consumption of sulphuric acid $\left(\mathrm{H}_{2} \mathrm{SO}_{4}\right)$ during the production of phosphoric acid. Calcination gives therefore a product that fulfils the requirements of its use.

\section{References}

[1] Becker P (1989) Phosphates and Phosphoric acid, Marcel Decker.

[2] Bonel G (1972) Annales de Chimie (Paris) 7, 127-144.

[3] CHAABOUNI A, CHTARA C, NZIHOU A \& EL FEKI H (2013) Kinetic Study of the Dissolution of Tunisian Natural Phosphate or Francolite in Industrial Phosphoric Acid. Journal of Advances in Chemistry 6, 908-916.

[4] Chien SH \& Black CA (1976) Free energy of formation of carbonate apatites in some phosphate rocks. Soil Science Society of America Journal 40, 234-239.

[5] EL FEKI H, KHATTECH I, JEMAL M \& Rey C (1994) Décomposition thermique d'hydroxyapatites carbonatées sodées Thermochimica Acta 237, 99-110.

[6] EL FEKI H, KHATTECH I \& JEMAL M (1991) Décomposition thermique de fluorapatites carbonatées sodées. Journal de Chimie Physique 88, 1885-1892.

[7] EL FEKI H, Rey C \& Vignoles M (1991) Carbonate ions in apatites: Infrared investigations in the $v_{4} \mathrm{CO}_{3}$ domain. Calcified Tissue International 49, 269-274.

[8] Elliott JC (1994) Structure and Chemistry of the Apatites and Other Calcium Orthophosphates. Elsevier, Amsterdam.

[9] Jahnke RA (1984) the synthesis and solubility of carbonate fluorapatite. American Journal of Science 290, 58-78.

[10] Kumar D (1980) Calcination of phosphate rocks. Chemie Ingenieur Technik 52, 736-740.

[11]LABARTHE JC, Bonel G \& MONTEL G (1973) Annales de Chimie Paris 8, 289-301.

[12]Lafon JP, Champion E \& Assollant DB (2002) Caractérisation d'apatites phosphocalciques carbonatées. Matériaux.

[13]Legeros RZ (1967) Ph.D., Thesis, New York University.

[14]Legeros RZ, Legeros JP, Trautz OR \& Klein E (1964) Journal of Dental Research 43, 75.

[15]Lehr JR, McClellan GH, Smith JP \& Frazier AW (1972) Phosphates dans l'agriculture: Colloque international sur les phosphates minéraux solides, Toulouse.

[16]McConnell D (1973) Apatite: its Crystal Chemistry, Mineralogy, Utilization, and Geologic and Biologic Occurrences, Springer-Verlag, Berlin.

[17]Memminger GG, Waggaman WH \& Whitney WT (1930) the calcination or enrichment of phosphate rock. Journal of Industrial and Engineering Chemistry 22, 443-446.

[18] Ozer AK (2003) the characteristics of phosphate rock in a fluidized bed for the upgrading. Advanced Powder Technology 14, 33-42.

[19]SLACK AV (1968) PHOSPHORIC ACID, MARCEL DEKKER. INC NEW YORK, and Volume I, Part I, 129.

[20]Trombe JC, Bonel G \& Montel G (1967) Comptes Rendus de l'Académie des Sciences Series C 265, 1113.

[21]Trombe JC (1973) Contribution à l'étude de la décomposition et de la réactivité de certaines apatites hydroxylées et carbonatées. Annales de Chimie 8, 251-269.

[22]Vignoles M (1984) Contribution à l'étude des apatites carbonatées de type $B$. Thèse d'état. Toulouse.

[23]Vignoles C (1973) Thèse de 3ème cycle, Université Paul Sabatier de Toulouse.

[24] Waggaman WmH (1953) PHSPHORIC ACID, PHOSPHATES AND PHOSPHATIC FERTILIZERS. SECOND EDITION, Second Printing, 183.

[25] Young RA (1973) Colloque International CNRS, Paris 230, 21. 